\title{
Methyl prednisolone and lung function after cardiopulmonary bypass
}

\author{
D H ENDERBY, A BOYLETT, AND D J PARKER \\ From National Heart Hospital, London W1, and St George's Hospital, London SW1, UK
}

\begin{abstract}
Thirty-one patients who were undergoing cardiopulmonary bypass for elective aortic valve replacement were studied. The effects on some aspects of lung function of intravenous methyl prednisolone, administered immediately before bypass, were assessed by measuring alveolar-arterial oxygen differences and shunt fractions. No significant differences in pulmonary function were found between the treated and control groups. The use of methyl prednisolone in this context is not justified.
\end{abstract}

Although the frequency and severity of pulmonary dysfunction after open intracardiac surgery using cardiopulmonary bypass has decreased, it may cause significant morbidity and is occasionally the primary factor in mortality. The aetiology of pulmonary dysfunction has been disputed since the early days of open heart surgery, and no consensus exists at present. Denaturation of plasma proteins (Lee et al, 1961 ; Pruitt et al, 1971) at the gas air interface in the oxygenator has been the most widely supported cause. It is postulated that damage to the pulmonary capillary membrane is an essential feature of the classic pathological findings, which in all degrees are associated with an increase in interstitial alveolar fluid (Baer and Osborn, 1960). Wilson (1972) proposed that polymorphonuclear leucocytes and platelets may be incriminated in the presumed membrane damage and suggested that methyl prednisolone hemisuccinate could reduce it. He reported a significant reduction in membrane damage in patients undergoing cardiopulmonary bypass who received methyl prednisolone, as assessed by lung biopsy at the end of operation. However, there was no physiological evidence to support the histological evidence. Extravascular lung water, measured by a double indicator dilution technique, increases after cardiac surgery using extracorporeal circulation. There was no change in the colloid and hydrostatic forces that act on the capillary membrane (Parker et al, 1972). These changes are associated with a deterioration in the gas exchange of the lungs, which is maximal about 48 hours after operation and has not returned to normal after seven days.

To determine whether methyl prednisolone hemisuccinate can produce changes in gas exchange to parallel the changes in histology, a double-blind trial of the effect of the drug given immediately before the onset of bypass has been undertaken.

\section{Methods}

Thirty-one patients who were undergoing elective operations for aortic valve disease were studied. A standard random selection technique was used, excluding any patients with obvious lung disease or frank left ventricular failure. Informed consent for the investigations was obtained and if at any time the subject found the tests intolerable the study on that patient was terminated, and the results excluded. These exclusions account for the odd numbered total. Investigations were performed at the following time intervals: (1) before operation, (2) 48 hours after operation, and (3) one week after operation.

The investigation consisted of arterial blood sampling while the subjects breathed first room air, and then $100 \%$ oxygen via an anaesthetic circuit. The arterial blood samples were obtained from a 20-gauge cannula that was placed in the radial artery ten minutes before each test, this time being allowed for the patient to settle after the disturbance of the arterial puncture. In the two patients in whom it was not practical to place an intra-arterial cannula, arterial sampling was by puncture of a brachial or femoral artery.

A three-way tap was attached to the intra-arterial cannula. For sampling, the tap was opened and arterial blood allowed to wash out the cannula deadspace for one to two seconds before the sample was taken in a heparinised glass syringe, which was then capped. The time between collection and analysis was 
between 20 seconds and five minutes. This wasrecorded and appropriate corrections made for changes of gas tensions with elapsed time (Kelman and Nunn, 1966). The first sample was obtained 10 minutes after insertion of the cannula, and the second after 15 minutes breathing $100 \%$ oxygen.

The patients were oxygenated using a Mapleson C anaesthetic circuit supplied with a fresh gas flow of $15 \mathrm{l} / \mathrm{min}$ of oxygen. They wore a spring noseclip and breathed through a rubber mouthpiece for $15 \mathrm{~min}$ utes, or until sequential arterial specimens showed consistently similar values. This method of oxygenation, while undoubtedly superior to other techniques in producing satisfactory oxygenation of the blood, was the sole reason for patients finding the tests intolerable, since it is neither particularly easy nor comfortable.

After the preoperative investigations the patients were placed in two groups, one receiving $30 \mathrm{mg} / \mathrm{kg}$ of methyl prednisolone intravenously 5-10 mins before the start of cardiopulmonary bypass, and the other group receiving no steroid and no placebo. In every other respect the two groups were identical.

\section{APPARATUS}

The blood samples were analysed on an IL 213 blood gas analyser. This model was chosen since it has simultaneous $\mathrm{Po}_{2}$ and $\mathrm{PCO}_{2}$ gas analysis and an extremely small dead space between injection port and analysis electrodes. The suitability of this analyser for these measurements was assessed using human blood, which was tonometered with different gas tensions to assess blood/gas differences and to construct a calibration.graph (fig) for which an IL 237 tonometer and temperature controller 227 were used.

Calibration of the electrodes was with gas mixtures (a) $\mathrm{O}_{2} 12 \%, \mathrm{CO}_{2} 5 \%, \mathrm{~N}_{2} 83 \%$, and (b) $\mathrm{O}_{2} 0 \%, \mathrm{CO}_{2}$

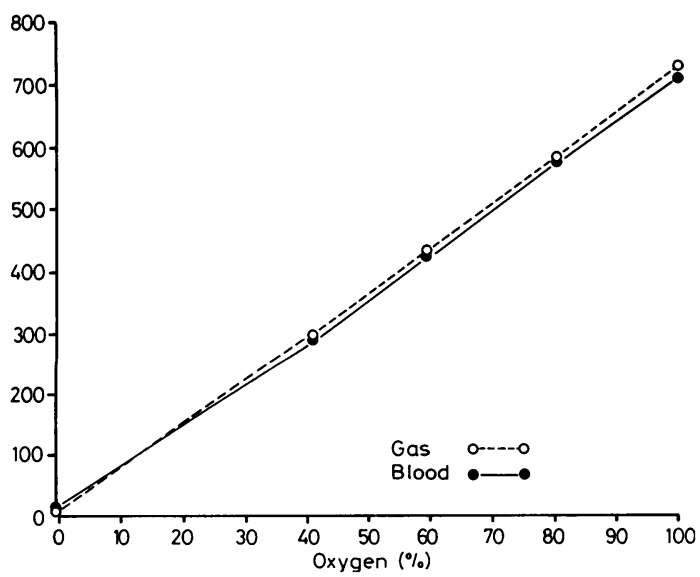

Blood/gas differences for the IL 213 blood gas analyser (ordinate $\mathrm{PO}_{\mathrm{O} . \text { ). }}$

$10 \%, \mathrm{~N}_{2} 90 \%$. The $\mathrm{Po}_{2}$ and $\mathrm{PcO}_{2}$ values were corrected for variation in ambient atmospheric pressure, and any differences stated on the manufacturers calibration certificates on the cylinder. Blood was tonometered for $\mathbf{4 0}$ minutes with a gas flow of 500 $\mathrm{ml} / \mathrm{min}$ at $37^{\circ} \mathrm{C}$. Only after this length of time could reproducible readings be obtained. Samples were transferred from the tonometer to the IL 213 blood gas analyser with a glass syringe. Readings were repeated until consistent values were obtained, though usually only three were needed.

The figure shows the blood/gas differences obtained using this method for this particular analyser. The graph was used to correct the readings obtained in this study.

Haemoglobin for oxygen content calculations was estimated with a Coulter haemoglobinometer.

\section{CALCULATIONS}

Pulmonary function was assessed by the venous-toarterial shunt fraction calculated from the following expression;

$$
{ }^{*} \dot{\mathrm{Q}}_{\mathrm{s}}=\frac{\mathrm{C}_{\mathrm{c}} \mathrm{O}_{2}-\mathrm{C}_{\mathrm{a}} \mathrm{O}_{2}}{\mathrm{Q}_{\mathrm{c}} \mathrm{O}_{2}-\mathrm{C}_{\overline{\mathrm{v}}} \mathrm{O}_{2}}
$$

$\mathrm{C}_{c} \mathrm{O}_{2}$ was calculated by assuming $\mathrm{P}_{c} \mathrm{O}_{2}$ to be equal to $\mathrm{PAO}_{2}$. The $\mathrm{PAO}_{2}$ was derived from the following expression of the alveolar air equation;

$$
\mathrm{PAO}_{2}=\mathrm{PIO}_{2}-\frac{\mathrm{PACO}_{2}}{\mathrm{R}} \text { where } \mathrm{R}=0 \cdot 8
$$

We appreciate that other forms of the alveolar air equation may be applicable under different circumstances. Any error in calculated $\mathrm{PAO}_{2}$ using this form of the equation is small, however, and in terms of oxygen content, insignificant. Furthermore, the purpose of the calculations is to compare two groups of patients and thus any systematic error is equally applicable to both groups. $\mathrm{P}_{\mathrm{aCO}_{2}}$ was measured directly from the arterial blood and the $\mathrm{PACO}_{2}$ assumed to be equivalent to this value.

Mixed venous oxygen tensions were measured 48 hours after operation from blood drawn from an indwelling catheter that had been placed at operation in the main pulmonary artery through the right ventricular outflow tract. From the mixed venous and arterial oxygen tensions the arterial-venous oxygen content difference was then calculated. This was performed in 21 of the 31 patients, and a mean $\mathrm{Ca}-\overline{\mathrm{v}}$ difference of $5 \cdot 79+0.99 \mathrm{vol} \%$ was obtained. For the patients in whom no pulmonary artery specimen was obtainable, a figure for the $\mathrm{Ca}-\overline{\mathrm{v}}$ difference of 6 vol \% was used. It is appreciated that differences in

$$
\begin{aligned}
& \text { *Definitions: } \\
& \mathbf{P}=\text { Partial pressure } \quad \dot{c}=\text { End capillary } \\
& \mathbf{A}=\text { Alveolar } \\
& \text { I = Inspired } \\
& \mathrm{C}=\text { Content }
\end{aligned}
$$


cardiac output may be responsible for changes in a $-\bar{v}-$ content differences. It is known (Parker, 1975), however, that any change in cardiac output $\mathbf{4 8}$ hours after operation in this group of patients is unlikely to be large. For intergroup comparisons therefore, this method is quite satisfactory.

All conversions of partial pressure to content were performed from the tables of Kelman and Nunn(1968) embodying the standard corrections for $\mathrm{pH}$, temperature, bicarbonate, and haemoglobin.

\section{Results}

From the blood gas analyses, the following information was obtained for the two groups before operation, 48 hours after operation, and one week after operation: (1) $\mathrm{PaO}_{2}$ and $\mathrm{PaCO}_{2}$ breathing air and oxygen; (2) $\mathrm{A}-\mathrm{adO}_{2}$ breathing air and oxygen; and (3) shunt fraction $\dot{Q}_{s} / Q_{t}$ breathing $O_{2}$ less $\dot{Q}_{s} / \dot{Q}_{t}$ breathing air.

The results were analysed as follows: group 1-the whole group with no exclusions, and group 2-the group excluding all patients with preoperative shunt values on air exceeding $10 \%$ (five out of 15 in the treated group, two out of 16 in the untreated group).

This exclusion of patients with large shunt values on air before operation was performed to exclude those with probable subclinical pulmonary oedema (McCredie, 1967). The results both with and without these exclusions are shown. Cross comparisons were made to see if there were statistically significant differences between the two groups of patients at any time, or within the groups at the different times.

Statistical analysis was performed by application of Student's paired $t$ tests, for which a plotting programme for an Eliot 903 computer was used. Differences were taken as significant when the value for $t$ was such that $P$ was less than 0.05 .

\section{SHUNT FRACTIONS}

Table 1 shows the values for shunt fractions, breathing air or oxygen.

(1) The selection of patients, being random, was contributory to placing five patients with shunt values on air considerably over $10 \%$ in the treated group and only two in the untreated group. This accounts for a significant difference between the two groups before operation when the whole series is considered, but not when the exclusions as described previously were applied.

(2) When considering shunt on oxygen alone, the actual shunt changes between before operation and 48 hours, 48 hours and one week, and before operation and one week were all significant (between $\mathrm{P}>0.05$ and $\mathrm{P}>0.001$ ) with paired $t$ testing in both the treated group and untreated groups, both in the whole group, and in the group excluding shunts in air over $10 \%$. When considering the shunt on air, the findings are similar ( $P$ between $>0.05$ and $>0.001$ ) at the three times. However, unpaired $t$ testing (comparing treated against untreated groups) shows no significance at any time in either the whole group

Table 1 Values for shunt fractions breathing air and oxygen

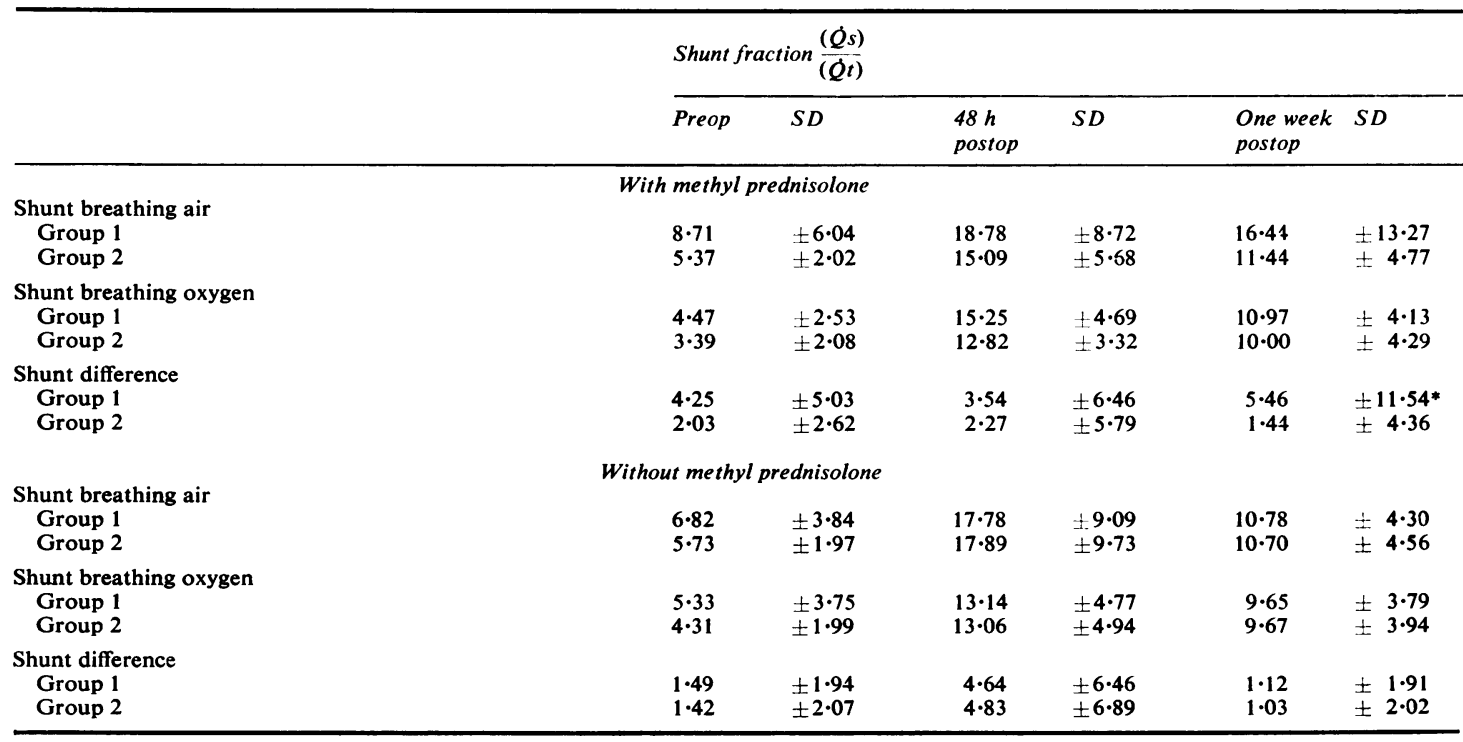

Group 1 = Whole group; Group 2 = Group excluding patients with shunt values on air greater than $10 \%$ before operation.

*This group includes one patient with a calculated shunt difference of $42 \%$ at one week after operation. 
or the subgroup with exclusions.

(3) When considering shunt differences-that is, shunt on oxygen less shunt on air-the differences between before operation and 48 hours after operation, 48 hours and one week, and before operation and one week are not significant in the treated group, but the differences are significant in the untreated group between before operation and 48 hours and one week both in the whole group and in the group excluding shunts on air of over $10 \%$.

It is not justifiable to draw conclusions from this, other than to point out that the treated group showed no significant changes at the three different times whereas the untreated group did. When considering the actual shunt values, however, the differences between the treated and untreated groups were not significantly different at either $\mathbf{4 8}$ hours or one week.

\section{ARTERIAL OXYGEN TENSIONS}

Table 2 shows the values for $\mathrm{PaO}_{2}$ obtained while breathing air or oxygen. Cross comparisons in both directions were made (using $t$ testing) as follows; the figures were compared before operation against 48 hours, 48 hours against one week, and before operation against one week, in the whole groups and the exclusion groups, while breathing air or oxygen, for both the treated and untreated groups. The results at each time interval in each group of the treated patients were then compared against the results in the corresponding groups of untreated patients.

The conclusions were as follows:

(1) There were significant falls in $\mathrm{PaO}_{2}$ while breathing either air or oxygen at 48 hours from before operation, and significant rises again at one week after operation from the 48-hour values, but these values were still significantly lower than the preoperative values.
(2) There were no significant differences between the two groups - that is, treated compared with untreated at any time before or after operation.

\section{ARTERIAL CARBON DIOXIDE TENSIONS}

Table 3 shows the values for $\mathrm{PaCO}_{2}$ obtained while breathing air or oxygen. Comparisons were made exactly as for table 1 . The conclusions were that there were no significant differences when breathing air or oxygen in either group - that is, treated compared with untreated-at any time except when breathing oxygen before operation, when the group scheduled not to receive methyl prednisolone in the subgroup excluding shunts over $10 \%$ had significantly lower $\mathrm{PaCO}_{2}$ values than the group scheduled for treatment. It will be seen from looking at the actual figures (asterisked in table 3) that this is an unimportant change for two reasons: (1) the relatively small number of patients excluded from these subgroups (vide supra) and (2) there is no significant difference between the $\mathrm{PaCO}_{2}$ values in the total group and the subgroups with the exclusions.

\section{ALVEOLAR-ARTERIAL OXYGEN TENSION DIFFERENCES}

Table 4 shows the alveolar-arterial $\mathrm{Po}_{2}$ differences in the patients breathing air or oxygen. Comparisons were made exactly as in the previous tables. As might be expected from the $\mathrm{PaO}_{2}$ results, there are significant rises in $\mathrm{A}-\mathrm{adO}_{2}$ at 48 hours after operation when breathing air or oxygen. These changes are significant in all the groups both with and without methyl prednisolone. The $\mathrm{A}-\mathrm{adO}_{2}$ decreases again at one week, but is only significantly different from the 48-hour values in the following respects: (1) in the whole group, without methyl prednisolone, breathing oxygen (not in the exclusion subgroup); (2) in the whole group only, with methyl prednisolone,

Table 2 Arterial oxygen tensions $\left(\mathrm{PaO}_{2}(\mathrm{mmHg})\right)$

\begin{tabular}{|c|c|c|c|c|c|c|}
\hline & Preop & $S D$ & $\begin{array}{l}48 h \\
\text { postop }\end{array}$ & $S D$ & $\begin{array}{l}\text { One week } \\
\text { postop }\end{array}$ & $S D$ \\
\hline \multicolumn{7}{|c|}{ With methyl prednisolone } \\
\hline $\begin{array}{c}\text { Breathing air } \\
\text { Group } 1 \\
\text { Group } 2\end{array}$ & $\begin{array}{l}78 \cdot 0 \\
83 \cdot 5\end{array}$ & $\begin{array}{l} \pm 10 \cdot 3 \\
\pm 5 \cdot 8\end{array}$ & $\begin{array}{l}55 \cdot 2 \\
59 \cdot 5\end{array}$ & $\begin{array}{l} \pm \quad 9 \cdot 2 \\
\pm \quad 7 \cdot 2\end{array}$ & $\begin{array}{l}64 \cdot 2 \\
69 \cdot 1\end{array}$ & $\begin{array}{l} \pm 13 \cdot 7 \\
\pm 8 \cdot 6\end{array}$ \\
\hline $\begin{array}{c}\text { Breathing ox } \\
\text { Group 1 } \\
\text { Group } 2\end{array}$ & $\begin{array}{l}584 \cdot 0 \\
597 \cdot 9\end{array}$ & $\begin{array}{l} \pm 39 \cdot 9 \\
\pm 38 \cdot 3\end{array}$ & $\begin{array}{l}356 \cdot 1 \\
413 \cdot 9\end{array}$ & $\begin{array}{l} \pm 106 \cdot 5 \\
\pm 58 \cdot 5\end{array}$ & $\begin{array}{l}453 \cdot 9 \\
472 \cdot 2\end{array}$ & $\begin{array}{l} \pm 79 \cdot 9 \\
\pm 79 \cdot 8\end{array}$ \\
\hline \multicolumn{7}{|c|}{ Without methyl prednisolone } \\
\hline $\begin{array}{l}\text { Group } 1 \\
\text { Group } 2\end{array}$ & $\begin{array}{l}81 \cdot 2 \\
82 \cdot 1\end{array}$ & $\begin{array}{l} \pm 5 \cdot 9 \\
\pm 5 \cdot 7\end{array}$ & $\begin{array}{l}58 \cdot 8 \\
59 \cdot 1\end{array}$ & $\begin{array}{l} \pm 11 \cdot 5 \\
\pm 12 \cdot 3\end{array}$ & $\begin{array}{l}69 \cdot 9 \\
70 \cdot 7\end{array}$ & $\begin{array}{l} \pm 10 \cdot 0 \\
\pm 10 \cdot 2\end{array}$ \\
\hline $\begin{array}{l}\text { Breathing ox } \\
\text { Group 1 } \\
\text { Group } 2\end{array}$ & $\begin{array}{l}585 \cdot 9 \\
591 \cdot 9\end{array}$ & $\begin{array}{l} \pm 37 \cdot 1 \\
\pm 34 \cdot 9\end{array}$ & $\begin{array}{l}384 \cdot 3 \\
384 \cdot 9\end{array}$ & $\begin{array}{l} \pm 115.6 \\
\pm 117.8\end{array}$ & $\begin{array}{l}490 \cdot 9 \\
492 \cdot 5\end{array}$ & $\begin{array}{l} \pm 80.3 \\
\pm 83.7\end{array}$ \\
\hline
\end{tabular}

SI conversion factor: $100 \mathrm{mmHg}=13 \cdot 3 \mathrm{kPa}$.

Group 1 =Whole group; Group 2 excluding patients with shunt values on air greater than $10 \%$ before operation. 
Table 3 Arterial carbon dioxide tensions $\left(\mathrm{PaCO}_{2}(\mathrm{mmHg})\right)$

\begin{tabular}{|c|c|c|c|c|c|c|}
\hline & Preop & $S D$ & $\begin{array}{l}48 h \\
\text { postop }\end{array}$ & $S D$ & $\begin{array}{l}\text { l week } \\
\text { postop }\end{array}$ & $S D$ \\
\hline \multicolumn{7}{|c|}{ With methyl prednisolone } \\
\hline $\begin{array}{c}\text { Breathing air } \\
\text { Group } 1 \\
\text { Group } 2\end{array}$ & $\begin{array}{l}37 \cdot 3 \\
38 \cdot 3\end{array}$ & $\begin{array}{l} \pm 3 \cdot 8 \\
\pm 4 \cdot 1\end{array}$ & $\begin{array}{l}37 \cdot 5 \\
38 \cdot 2\end{array}$ & $\begin{array}{l} \pm 3 \cdot 9 \\
\pm 4 \cdot 2\end{array}$ & $\begin{array}{l}34 \cdot 0 \\
33 \cdot 9\end{array}$ & $\begin{array}{l} \pm 3 \cdot 2 \\
\pm 3 \cdot 9\end{array}$ \\
\hline $\begin{array}{c}\text { Breathing ox } \\
\text { Group } 1 \\
\text { Group } 2\end{array}$ & $\begin{array}{l}39 \cdot 0 \\
41 \cdot 9 *\end{array}$ & $\begin{array}{l} \pm 7 \cdot 1 \\
\pm 6 \cdot 5\end{array}$ & $\begin{array}{l}39 \cdot 9 \\
39 \cdot 9\end{array}$ & $\begin{array}{l} \pm 5 \cdot 6 \\
\pm 5 \cdot 1\end{array}$ & $\begin{array}{l}35 \cdot 7 \\
36 \cdot 2\end{array}$ & $\begin{array}{l} \pm 5 \cdot 6 \\
\pm 5 \cdot 7\end{array}$ \\
\hline \multicolumn{7}{|c|}{ Without methyl prednisolone } \\
\hline $\begin{array}{l}\text { Group } 1 \\
\text { Group } 2\end{array}$ & $\begin{array}{l}37 \cdot 9 \\
38 \cdot 0\end{array}$ & $\begin{array}{l} \pm 2 \cdot 9 \\
\pm 2 \cdot 4\end{array}$ & $\begin{array}{l}36 \cdot 7 \\
37 \cdot 3\end{array}$ & $\begin{array}{l} \pm 3 \cdot 2 \\
\pm 2 \cdot 9\end{array}$ & $\begin{array}{l}32 \cdot 7 \\
32 \cdot 4\end{array}$ & $\begin{array}{l} \pm 3 \cdot 4 \\
\pm 3.5\end{array}$ \\
\hline $\begin{array}{c}\text { Breathing ox } \\
\text { Group } 1 \\
\text { Group } 2\end{array}$ & $\begin{array}{l}36 \cdot 6 \\
36 \cdot 3^{*}\end{array}$ & $\begin{array}{l} \pm 5 \cdot 3 \\
\pm 5 \cdot 6\end{array}$ & $\begin{array}{l}38 \cdot 0 \\
38 \cdot 2\end{array}$ & $\begin{array}{l} \pm 3.9 \\
\pm 3.5\end{array}$ & $\begin{array}{l}33 \cdot 4 \\
33 \cdot 4\end{array}$ & $\begin{array}{l} \pm 3 \cdot 6 \\
\pm 3 \cdot 8\end{array}$ \\
\hline
\end{tabular}

SI conversion factor: $100 \mathrm{mmHg}=13 \cdot 3 \mathrm{kPa}$.

Group 1 =Whole group; Group 2=Group excluding patients with shunt values on air greater than $10 \%$ before operation.

*See text.

Table 4 Alveolar-arterial oxygen tension differences $\left(A-a d \mathrm{O}_{2}(\mathrm{mmHg})\right)$

\begin{tabular}{|c|c|c|c|c|c|c|}
\hline & Preop & $S D$ & $\begin{array}{l}48 h \\
\text { postop }\end{array}$ & $S D$ & $\begin{array}{l}\text { One week } \\
\text { postop }\end{array}$ & $S D$ \\
\hline \multicolumn{7}{|c|}{ With methyl prednisolone } \\
\hline $\begin{array}{c}\text { Breathing air } \\
\text { Group } 1 \\
\text { Group } 2\end{array}$ & $\begin{array}{l}25 \cdot 4 \\
18 \cdot 6\end{array}$ & $\begin{array}{l} \pm 12 \cdot 2 \\
\pm 6.6\end{array}$ & $\begin{array}{l}46 \cdot 3 \\
41 \cdot 5\end{array}$ & $\begin{array}{l} \pm 10.7 \\
\pm \quad 9.0\end{array}$ & $\begin{array}{l}40 \cdot 1 \\
34 \cdot 8\end{array}$ & $\begin{array}{l} \pm 14.4 \\
\pm 8.4\end{array}$ \\
\hline $\begin{array}{c}\text { Breathing ox } \\
\text { Group } 1 \\
\text { Group } 2\end{array}$ & $\begin{array}{l}86 \cdot 4 \\
60 \cdot 7\end{array}$ & $\begin{array}{l} \pm 55 \cdot 8 \\
\pm 38 \cdot 8\end{array}$ & $\begin{array}{l}306 \cdot 5 \\
251 \cdot 5\end{array}$ & $\begin{array}{l} \pm 102 \cdot 5 \\
\pm 57 \cdot 4\end{array}$ & $\begin{array}{l}210 \cdot 5 \\
192 \cdot 9\end{array}$ & $\begin{array}{l} \pm 82 \cdot 3 \\
\pm 85.4\end{array}$ \\
\hline \multicolumn{7}{|c|}{ Without methyl prednisolone } \\
\hline $\begin{array}{c}\text { Breathing air } \\
\text { Group } 1 \\
\text { Group } 2\end{array}$ & $\begin{array}{l}20 \cdot 7 \\
19 \cdot 6\end{array}$ & $\begin{array}{l} \pm 7.9 \\
\pm 7.4\end{array}$ & $\begin{array}{l}45 \cdot 3 \\
44 \cdot 1\end{array}$ & $\begin{array}{l} \pm 11 \cdot 4 \\
\pm 11.7\end{array}$ & $\begin{array}{l}37 \cdot 9 \\
37 \cdot 5\end{array}$ & $\begin{array}{l} \pm 11 \cdot 1 \\
\pm 11 \cdot 3\end{array}$ \\
\hline $\begin{array}{c}\text { Breathing ox } \\
\text { Group } 1 \\
\text { Group } 2\end{array}$ & $\begin{array}{l}81 \cdot 5 \\
75 \cdot 6\end{array}$ & $\begin{array}{l} \pm 37 \cdot 5 \\
\pm 35 \cdot 3\end{array}$ & $\begin{array}{l}285 \cdot 2 \\
283 \cdot 5\end{array}$ & $\begin{array}{l} \pm 114 \cdot 0 \\
\pm 114 \cdot 9\end{array}$ & $\begin{array}{l}180 \cdot 2 \\
180 \cdot 4\end{array}$ & $\begin{array}{l} \pm 76.6 \\
\pm 79.4\end{array}$ \\
\hline
\end{tabular}

SI conversion factor $100 \mathrm{mmHg}=13 \cdot 3 \mathrm{kPa}$.

Group 1 = Whole group; Group 2=Group excluding patients with shunt values on air greater than $10 \%$ before operation.

breathing air; and (3) in both groups - that is, whole group and subgroup with methyl prednisolone breathing oxygen. It is difficult to draw any conclusion from this particular result, since there are no significant differences between the treated and untreated groups at any time.

\section{Discussion}

Although Wilson (1972) reported a pronounced reduction in the histological pattern occurring after open heart surgery in patients treated with methyl prednisolone, this study does not show any significant difference in the gas exchange of the lungs between treated and non-treated patients. There are several possible explanations for this. The deterioration in gas exchange may not be associated with the changes in the pulmonary capillary membrane caused by leucocyte and platelet adhesion. Possibly, although the platelet and white cell adhesion is reduced by methyl prednisolone, there is still enough membrane damage to produce the same physiological effects on gas exchange.

Furthermore at least a proportion of the changes could be due to the median sternotomy, but there are no studies comparing patients who have had a median sternotomy, with and without cardiopulmonary bypass. There is some evidence to confirm that white cells and platelets are sequestered in the lungs at the onset of the operation (Parker, 1975), but no study has been performed to determine whether methyl prednisolone will influence this change. Thus although methyl prednisolone hemisuccinate may have a favourable influence on the histological appearance of the lungs, nothing suggests that pulmonary function is improved by treating patients with methyl pred- 
nisolone, and its widespread use for this purpose cannot be justified in patients undergoing open heart surgery. The group of patients who were operated on were not in heart failure and did not have significant pulmonary dysfunction. Whether a patient who has pre-existing pulmonary dysfunction or pronounced left ventricular failure would benefit from methyl prednisolone is not known. Further studies are required to establish any possible benefit of methyl prednisolone in such cases.

We thank Miss A L Peckar for her secretarial help.

\section{References}

Baer, D M, and Osborn, J J (1960). The post-perfusion pulmonary congestion syndrome. American Journal of Clinical Pathology, 34, 442-445.

Kelman, G R, and Nunn, J F (1966). Nomograms for correction of blood $\mathrm{pO}_{2}, \mathrm{pCO}_{2}, \mathrm{pH}$, and base excess for time and temperature. Journal of Applied Physiology, 21, 1484-1490.

Kelman, G R, and Nunn, J F (1968). Computer Produced Physiological Tables. Butterworths: London.
Lee, W H, jun, Krumhaar, D, Fonkalsrud, E W, Scheide, O A, and Maloney, J N, jun (1961). Denaturation of plasma proteins as a cause of morbidity and death after intracardiac operations. Surgery, 50, 29-39.

McCredie, M (1967). Measurement of pulmonary edema in valvular heart disease. Circulation, 36, 381-386.

Parker, D J, Karp, R B, Kirklin, J W, and Bedard, P (1972). Lung water and alveolar and capillary volumes after intracardiac surgery. Circulation, 45, suppl 1, 139-146.

Parker, D J (1975). Some changes in the lungs associated with cardiopulmonary bypass. In Lung Metabolism, edited by A F Junod and R de Haller, pp 459-479. Academic Press, New York.

Pruitt, K M, Stroud, R M, and Scott, J W (1971). Blood damage in the heart-lung machine. Proceedings of the Society for Experimental Biology and Medicine, 137, 714-718.

Wilson, J W (1972). Treatment or prevention of pulmonary cellular damage with pharmacologic doses of corticosteroid. Surgery, Gynaecology, and Obstetrics, 134, 675-681.

Requests for reprints to: Mr D J Parker, St George's Hospital, Hyde Park Corner, London SW1. 